\title{
An Empirical Study on the International Competitiveness of China's Service Trade after the Accession to WTO
}

\author{
Rong Wang \\ ${ }^{1}$ Changchun Guanghua University, Changchun, Jilin, China \\ a374650147@qq.com
}

Keywords: China, service trade, international competitiveness.

\begin{abstract}
The study analyzes the import and export volume of China's service trade from 2002 to 2013. We adopt three indexes to assess the international competitiveness of China's service trade, export market share, trade competitiveness index and revealed comparative advantages. And we propose some strategies to improve the competitiveness of China's service trade.
\end{abstract}

\section{Introduction}

In recent years, with the in-depth development of economic globalization, as well as the continuous progress and development of science and technology, the upgrading and transformation of the world's industrial structure has speeded up. The world industrial development pattern has shifted from agriculture and industry to service. At present, most developed countries have established a new industrial structure, which is mainly based on service. The rapid development of modern service industry creates the basic conditions for the development of international service trade, which promotes the development of world trade. With the fast development of service trade, the focus of global economic competitiveness has shifted from goods to service. While evaluating a country's international competitiveness, its service trade is an important indicator. Its international competitiveness of service trade will affect a country's national economy in the future and its development of foreign trade.

In 2012, the import and export volume of China's service trade is \$ 470,6 billion. In 2013, the volume is $\$ 539.6$ billion. It was the first time the volume has reached to $\$ 500$ billion. Even facing the complex international environment, China's service trade has gradually developed. In 2013, China's service trade export has firstly increased with double-digit growth since 2011. In 2013, China's service trade deficit is \$ 118,457 billion, which shows that China's service trade deficit has further expanded.

\section{The Concept of International Service Trade and the Source of Data}

Service trade is also called labor trade. Simply speaking, it refers to the economic exchange activities between a country and another. According to the concept of service trade in General Agreement on Trade in Services (GATs) which is defined by WTO, it is has different ways to provide service. Based on GATs, service trade has four ways: cross-border delivery, foreign consumption, commercial presence and movement of natural persons.

The data in this paper is the data of China's international service trade and the world trade from 2002 to 2013. The reason why we choose this period is that China accessed to WTO in 2001. Therefore the data has shown the development of China's service trade since its accession. In addition, the date of this period has the certain practical significance. The data is original from the Ministry of Commerce, WTO International Trade Statistics Database and World Economic Database. 


\section{The Development Status of China's Service Trade}

The overall status of China's service trade. In 2002, the import and export volume of China's service trade is only $\$ 85,5$ billion. In 2003 , the volume is up to $\$ 101,3$ billion. In 2011, the volume is $\$ 419.1$ billion. In 2012, the volume is \$ 470,6 billion. In 2013, the volume is \$ 539.6 billion dollars. The specific import and export volume of China's service trade in each year is shown in Table 1.

Table 1 Import and export volume of China's service trade (unit: USD 100 million)

\begin{tabular}{|c|c|c|c|c|c|c|c|c|c|c|c|c|}
\hline Year & 2002 & 2003 & 2004 & 2005 & 2006 & 2007 & 2008 & 2009 & 2010 & 2011 & 2012 & 2013 \\
\hline $\begin{array}{c}\text { Import } \\
\text { and export }\end{array}$ & & & & & & & & & & & \\
$\begin{array}{c}\text { volume of } \\
\text { China's } \\
\text { service } \\
\text { trade }\end{array}$ & 855 & $\begin{array}{c}1,01 \\
3\end{array}$ & $\begin{array}{c}1,33 \\
7\end{array}$ & $\begin{array}{c}1,57 \\
1\end{array}$ & $\begin{array}{c}1,91 \\
7\end{array}$ & $\begin{array}{c}2,50 \\
9\end{array}$ & 3,045 & 2,867 & $\begin{array}{c}3,62 \\
4\end{array}$ & $\begin{array}{c}4,19 \\
1\end{array}$ & 4,706 & $\begin{array}{c}5,396 . \\
45\end{array}$ \\
\hline
\end{tabular}

Note: The data is original from Information Network Database of Development Research Center of the State Council, eliminating government service.

As shown in Table 1, we can see that in addition to the data in 2009 which is slightly decreased compared to that in 2008, the general import and export volume of China's service trade has been rising. In 2013, the import and export volume of China's service trade reached \$ 539,645 billion. The data increased 5.3 times compared to that in 2002, with an average annual growth of $53.1 \%$. Based on the changes of the import and export volume from 2002 to 2013, we can see that China's service trade has rapidly developed since its accession to WTO.

The import status of China's service trade. In 2002, the import of China's service trade is \$ 46.1 billion. In 2003, the import is \$ 54.9 billion. In 2011, the import is \$ 237.003 billion. In 2012, the import is \$ 280.1 billion. In 2013, the import is \$ 329.051 billion. Based on Table 2, we can see that the total import of China's service trade is growing every year during these ten years. The import of China's service trade is $\$ 46.1$ billion in 2002 while the import is $\$ 329.051$ billion in 2013. During the ten years, the import has increased by $\$ 282.951$ billion.

Table 2 The import and export of China's service trade from 2002 to 2013 (unit: USD 100 million)

\begin{tabular}{|c|c|c|c|c|c|c|c|c|c|c|c|c|}
\hline Year & $\begin{array}{c}200 \\
2\end{array}$ & $\begin{array}{c}200 \\
3\end{array}$ & $\begin{array}{c}200 \\
4\end{array}$ & $\begin{array}{c}200 \\
5\end{array}$ & 2006 & 2007 & 2008 & 2009 & 2010 & 2011 & 2012 & 2013 \\
\hline $\begin{array}{c}\text { Export of } \\
\text { China's } \\
\text { service trade }\end{array}$ & 394 & 464 & 621 & 739 & 914 & $\begin{array}{c}1,21 \\
6\end{array}$ & $\begin{array}{c}1,46 \\
5\end{array}$ & $\begin{array}{c}1,28 \\
6\end{array}$ & $\begin{array}{c}1,70 \\
2\end{array}$ & $\begin{array}{c}1,820.8 \\
7\end{array}$ & $\begin{array}{c}1,90 \\
5\end{array}$ & $\begin{array}{c}2,105.9 \\
4\end{array}$ \\
\hline $\begin{array}{c}\text { Import of } \\
\text { China's } \\
\text { service trade }\end{array}$ & 461 & 549 & 716 & 832 & $\begin{array}{c}1,00 \\
3\end{array}$ & $\begin{array}{c}1,29 \\
3\end{array}$ & $\begin{array}{c}1,58 \\
0\end{array}$ & $\begin{array}{c}1,58 \\
1\end{array}$ & $\begin{array}{c}1,92 \\
2\end{array}$ & $\begin{array}{c}2,370.0 \\
3\end{array}$ & $\begin{array}{c}2,80 \\
1\end{array}$ & $\begin{array}{c}3,290.5 \\
1\end{array}$ \\
\hline $\begin{array}{c}\text { China's service } \\
\text { trade balance }\end{array}$ & -67 & -85 & -95 & -93 & -89 & -77 & -115 & -295 & -220 & -549.16 & -896 & $\begin{array}{c}-1184.5 \\
7\end{array}$ \\
\hline
\end{tabular}

Note: The data is original from Information Network Database of Development Research Center of the State Council, eliminating government service.

The export status of China's service trade. In 2002, the export of China's service trade is $\$ 39,4$ billion. In 2003, the export is \$ 46,4 billion. In 2011, the export is \$ 182.087 billion. In 2012, the export is $\$ 190.5$ billion. In 2013, the export is \$ 210.594 billion. According to Table 2, we can see that from 2002 to 2013, except for some decline in 2009, the export of China's service trade is increasing. The total export volume of China's service trade increased from \$ 39,4 billion in 2002 to $\$ 210.594$ billion in 2013. The total export increased by $\$ 171.194$ billion.

The status of China's service trade balance. In 2002, China's services trade deficit is \$ 6.7 billion. In 2003, the deficit is $\$ 8.5$ billion. In 2011, the deficit is $\$ 54.916$ billion. In 2012, the deficit is $\$ 89.6$ billion. In 2013, the deficit is $\$ 118.457$ billion. Based on Table 2, we see that China's service trade has been in deficit for ten years from 2002 to 2013. In addition to the four years between 2004 
and 2007 in which the service trade deficit has declined, the annual service trade deficit is increasing in the other years. Especially from 2011 to 2013, China's service trade deficit has become larger and larger.

\section{Empirical Analysis of the International Competitiveness of China's Service Trade}

We analyze the competitiveness of China's service trade from three aspects, export market share, trade competitiveness index and revealed comparative advantages, which are the major measurements assessing international competitiveness.

Export market share of China's service trade. The export market share index is the ratio of a country's total export to the total world export, which shows the change of the overall competitiveness of a country's export. For a particular product or industry, this ratio can reflect the international competitiveness of the product or industry in this country. Its calculation formula is

$$
\mathrm{MS}_{\mathrm{ij}}=\mathrm{X}_{\mathrm{ij}} / \mathrm{X}_{\mathrm{wj}}
$$

$\mathrm{MS}_{\mathrm{ij}}$ refers to the market share index of product $\mathrm{j}$ in country $\mathrm{i} . \mathrm{X}_{\mathrm{ij}}$ refers to the total exports of product $\mathrm{j}$ in country $\mathrm{i}$. $\mathrm{X}_{\mathrm{wj}}$ refers to the total world export of product $\mathrm{j}$. Higher $\mathrm{MS}_{\mathrm{ij}}$ represents stronger international competitiveness, and the weaker the vice versa.

By analyzing the export market share of China's service trade, we acquire its overall competitiveness and the changes of its competitive position, and make the conclusion on the international competitiveness of China's service trade.

Table 3 Export market share of China's service trade from 2002 to 2013 (unit: USD 100 million)

\begin{tabular}{|c|c|c|c|c|c|c|c|c|c|c|c|c|}
\hline Year & 2002 & 2003 & 2004 & 2005 & 2006 & 2007 & 2008 & 2009 & 2010 & 2011 & 2012 & 2013 \\
\hline $\begin{array}{c}\text { China's service } \\
\text { trade exports }\end{array}$ & 394 & 464 & 621 & 739 & 914 & $\begin{array}{c}1,21 \\
7\end{array}$ & $\begin{array}{c}1,46 \\
4\end{array}$ & $\begin{array}{c}1,28 \\
6\end{array}$ & $\begin{array}{c}1,70 \\
2\end{array}$ & $\begin{array}{c}1,82 \\
1\end{array}$ & $\begin{array}{c}1,90 \\
4\end{array}$ & $\begin{array}{c}2,10 \\
6\end{array}$ \\
\hline $\begin{array}{c}\text { World service } \\
\text { trade exports }\end{array}$ & $\begin{array}{c}1596 \\
9\end{array}$ & $\begin{array}{c}1850 \\
0\end{array}$ & $\begin{array}{c}2247 \\
8\end{array}$ & $\begin{array}{c}2512 \\
7\end{array}$ & $\begin{array}{c}2841 \\
8\end{array}$ & $\begin{array}{c}3420 \\
3\end{array}$ & $\begin{array}{c}3846 \\
4\end{array}$ & $\begin{array}{c}3481 \\
4\end{array}$ & $\begin{array}{c}3819 \\
7\end{array}$ & $\begin{array}{c}4258 \\
3\end{array}$ & $\begin{array}{c}4349 \\
9\end{array}$ & $\begin{array}{c}4625 \\
0\end{array}$ \\
\hline $\begin{array}{c}\text { The ratio of } \\
\text { China's total } \\
\text { export to the } \\
\text { total world } \\
\text { export (\%) }\end{array}$ & 2.5 & 2.5 & 2.8 & 2.9 & 3.2 & 3.6 & 3.8 & 3.7 & 4.5 & 4.3 & 4.4 & 4.6 \\
\hline
\end{tabular}

Note: The data is original from WTO International Trade Statistics Database.

In 2002 and 2003, the ratio of China's total export to the total world export is 2.5\%. In 2004, the ratio is $2.8 \%$. In 2005 , the ratio is $2.9 \%$. In 2011 , the ratio is $4.3 \%$. In 2012, the ratio is $4.4 \%$. In 2013 , the ratio is $4.6 \%$. As shown in Table 3, the ratio of the total world export to China's total export is low, all within $4.7 \%$. This reflects that China's service trade is still lack of competitiveness. But based on the changes within these ten years, the ratio has been increasing except for individual year, which shows the increasing international competitiveness of China's service trade.

Trade competitiveness index. Trade competitiveness index (TC) is one of the common indicators of international competitiveness, which refers to the proportion of balance of trade to the total import and export trade volume. The formula is

$$
\mathrm{TC}_{\mathrm{ij}}=\left(\mathrm{X}_{\mathrm{ij}}-\mathrm{M}_{\mathrm{ij}}\right) /\left(\mathrm{X}_{\mathrm{ij}}+\mathrm{M}_{\mathrm{ij}}\right)
$$

$\mathrm{TC}_{\mathrm{ij}}$ refers to the trade competitiveness of product $\mathrm{j}$ in country $\mathrm{i} . \mathrm{X}_{\mathrm{ij}}$ refers to the export of product $\mathrm{j}$ in country $\mathrm{i} . \mathrm{M}_{\mathrm{ij}}$ refers to the import of product $\mathrm{j}$ in country $\mathrm{i}$.

The range of TC is between -1 and 1 . If TC is greater than zero, it indicates that this commodity has strong international competitiveness. The closer to 1 the value is, the stronger competitiveness it will be. If TC is less than zero, it indicates that this commodity does not have international competitiveness.

TC is a relative value of total trade, which excludes the influences of economic expansion, inflation and other macroeconomic factors. Regardless of the absolute volume of import and export volume, the indicator is between -1 and 1 . 
Table 4 Trade competitiveness index of China's service from 2002 to 2013

\begin{tabular}{|c|c|c|c|c|c|c|c|c|c|c|c|c|}
\hline Year & $\begin{array}{c}200 \\
2\end{array}$ & $\begin{array}{c}200 \\
3\end{array}$ & $\begin{array}{c}200 \\
4\end{array}$ & $\begin{array}{c}200 \\
5\end{array}$ & $\begin{array}{c}200 \\
6\end{array}$ & $\begin{array}{c}200 \\
7\end{array}$ & $\begin{array}{c}200 \\
8\end{array}$ & $\begin{array}{c}200 \\
9\end{array}$ & $\begin{array}{c}201 \\
0\end{array}$ & 2011 & $\begin{array}{c}201 \\
2\end{array}$ & 2013 \\
\hline $\begin{array}{c}\text { Export } \\
\text { volume of } \\
\text { service trade }\end{array}$ & 394 & 464 & 621 & 739 & 914 & $\begin{array}{c}1,21 \\
6\end{array}$ & $\begin{array}{c}1,46 \\
5\end{array}$ & $\begin{array}{c}1,28 \\
6\end{array}$ & $\begin{array}{c}1,70 \\
2\end{array}$ & $\begin{array}{c}1,820.8 \\
7\end{array}$ & $\begin{array}{c}1,90 \\
5\end{array}$ & $2,105.94$ \\
\hline $\begin{array}{c}\text { Import } \\
\text { volume of } \\
\text { service trade }\end{array}$ & 461 & 549 & 716 & 832 & $\begin{array}{c}1,00 \\
3\end{array}$ & $\begin{array}{c}1,29 \\
3\end{array}$ & $\begin{array}{c}1,58 \\
0\end{array}$ & $\begin{array}{c}1,58 \\
1\end{array}$ & $\begin{array}{c}1,92 \\
2\end{array}$ & $\begin{array}{c}2,370.0 \\
3\end{array}$ & $\begin{array}{c}2,80 \\
1\end{array}$ & $3,290.51$ \\
\hline $\begin{array}{c}\text { Trade } \\
\text { competitiven } \\
\text { ess index } \\
\left(\mathrm{TC}_{\mathrm{ij}}\right)\end{array}$ & -0.0 & -0.0 & -0.0 & -0.0 & -0.0 & -0.0 & -0.0 & -0.1 & -0.0 & -0.131 & -0.1 & -0.220 \\
\hline
\end{tabular}

Note: The data is original from Information Network Database of Development Research Center of the State Council, eliminating government service.

In 2002, $\mathrm{TC}_{\mathrm{ij}}$ of China's service is -0.078 . In 2003, $\mathrm{TC}_{\mathrm{ij}}$ of China's service is -0.084 . In 2004, $\mathrm{TC}_{\mathrm{ij}}$ of China's service is -0.071 . In 2010, $\mathrm{TC}_{\mathrm{ij}}$ of China's service is -0.061 . In 2011, $\mathrm{TC}_{\mathrm{ij}}$ of China's service is -0.131 . In 2012, $\mathrm{TC}_{\mathrm{ij}}$ of China's service is -0.190 . In 2013, $\mathrm{TC}_{\mathrm{ij}}$ of China's service is -0.220 . As shown in Table 4, we can see that from 2002 to 2013, the values of $\mathrm{TC}_{\mathrm{ij}}$ of China's service are all less than zero, which shows that the competitiveness of China's service trade is weak after its accession to WTO. Through further analysis, we can see that from 2003 to 2007, although the values of TC of China's service are all less than zero, the values gradually increased, indicating that during this period, the competitiveness of China's service trade has increased. From 2010 to 2013, TC of China's service gradually decreased, which indicates that the international competitiveness of China's service trade is weakening. Based on the data analysis, we can see that after China's accession to WTO, its service trade development is not comparative enough. The international competitiveness of our service trade is still weak.

Revealed comparative advantages. Revealed comparative advantages (RCA) is proposed by an American economist, Balassa. It shows the ratio of the export of a given product to its world export. Through RCA, we can see the comparative advantage of certain industry in a country (region). RCA can better reflect the relative advantages of a country's export and the world's average export level.

The calculation formula of RCA is

$\mathrm{RCA}_{\mathrm{st}}=\left(\mathrm{X}_{\mathrm{st}} / \mathrm{X}_{\mathrm{t}}\right) /\left(\mathrm{W}_{\mathrm{t}} / \mathrm{W}\right)$

$\mathrm{RCA}_{\mathrm{st}}$ refers to the revealed comparative advantages of product $t$ in country s. $\mathrm{X}_{\mathrm{st}}$ refers to the export of product $t$ of country s. $X_{t}$ refers to the exports of country s. $W_{t}$ refers to the world's total export of product t. W refers to the world's total exports.

By comparing RCA, we can judge the competitive position of a country's service trade in the world service. If RCA is larger than 2.5, it means that the country's service trade has very strong competitiveness. If RCA is less than 2.5 but larger than or equal to 1.25, the country's service trade has strong competitiveness. If RCA is less than 1.25 but larger than or equal to 0.8 , it means that the country's service trade has moderate competitiveness. If RCA is less than 0.8 , the competitiveness is relatively weak. 
Table 5 Revealed comparative advantages of China's service trade from 2002 to 2013

\begin{tabular}{|c|c|c|c|c|c|c|c|c|c|c|c|c|}
\hline Year & $\begin{array}{c}200 \\
2\end{array}$ & $\begin{array}{c}200 \\
3\end{array}$ & $\begin{array}{c}200 \\
4\end{array}$ & $\begin{array}{c}200 \\
5\end{array}$ & $\begin{array}{c}200 \\
6\end{array}$ & $\begin{array}{c}200 \\
7\end{array}$ & $\begin{array}{c}200 \\
8\end{array}$ & $\begin{array}{c}200 \\
9 \\
\end{array}$ & $\begin{array}{c}201 \\
0\end{array}$ & $\begin{array}{c}201 \\
1\end{array}$ & $\begin{array}{c}201 \\
2\end{array}$ & $\begin{array}{c}201 \\
3\end{array}$ \\
\hline $\begin{array}{l}\text { Export of China’s } \\
\text { service trade } \\
\text { (USD } 100 \text { million) }\end{array}$ & 394 & 464 & 645 & 739 & 914 & $\begin{array}{c}1,21 \\
7\end{array}$ & $\begin{array}{c}1,46 \\
4\end{array}$ & $\begin{array}{c}1,28 \\
5\end{array}$ & $\begin{array}{c}161 \\
2\end{array}$ & $\begin{array}{c}175 \\
7\end{array}$ & $\begin{array}{c}1,90 \\
4\end{array}$ & $\begin{array}{c}204 \\
7\end{array}$ \\
\hline $\begin{array}{l}\text { China's exports } \\
\text { (USD } 100 \text { million) }\end{array}$ & $\begin{array}{c}365 \\
0 \\
\end{array}$ & $\begin{array}{c}484 \\
6 \\
\end{array}$ & $\begin{array}{c}657 \\
8 \\
\end{array}$ & $\begin{array}{c}835 \\
9 \\
\end{array}$ & $\begin{array}{c}106 \\
04 \\
\end{array}$ & $\begin{array}{c}134 \\
22 \\
\end{array}$ & $\begin{array}{c}157 \\
71 \\
\end{array}$ & $\begin{array}{c}133 \\
01 \\
\end{array}$ & $\begin{array}{c}173 \\
90 \\
\end{array}$ & $\begin{array}{c}207 \\
41 \\
\end{array}$ & $\begin{array}{c}223 \\
91 \\
\end{array}$ & $\begin{array}{c}241 \\
37 \\
\end{array}$ \\
\hline $\begin{array}{l}\text { Export of world's } \\
\text { service trade } \\
\text { (USD } 100 \text { million) }\end{array}$ & $\begin{array}{c}159 \\
76\end{array}$ & $\begin{array}{c}185 \\
14\end{array}$ & $\begin{array}{c}225 \\
04\end{array}$ & $\begin{array}{c}251 \\
62\end{array}$ & $\begin{array}{c}284 \\
54\end{array}$ & $\begin{array}{c}342 \\
14\end{array}$ & $\begin{array}{c}384 \\
71\end{array}$ & $\begin{array}{c}348 \\
87\end{array}$ & $\begin{array}{c}382 \\
77\end{array}$ & $\begin{array}{c}429 \\
54\end{array}$ & $\begin{array}{c}439 \\
70\end{array}$ & $\begin{array}{c}464 \\
44\end{array}$ \\
\hline $\begin{array}{l}\text { World's exports } \\
\text { (USD } 100 \text { million) }\end{array}$ & $\begin{array}{c}809 \\
26 \\
\end{array}$ & $\begin{array}{c}944 \\
04 \\
\end{array}$ & $\begin{array}{l}114 \\
734 \\
\end{array}$ & $\begin{array}{l}130 \\
242 \\
\end{array}$ & $\begin{array}{l}149 \\
754 \\
\end{array}$ & $\begin{array}{l}174 \\
434 \\
\end{array}$ & $\begin{array}{l}200 \\
061 \\
\end{array}$ & $\begin{array}{l}160 \\
427 \\
\end{array}$ & $\begin{array}{l}191 \\
277 \\
\end{array}$ & $\begin{array}{l}226 \\
234 \\
\end{array}$ & $\begin{array}{l}228 \\
010 \\
\end{array}$ & $\begin{array}{l}234 \\
604\end{array}$ \\
\hline $\begin{array}{c}\text { Revealed comparative } \\
\text { advantages }\end{array}$ & $\begin{array}{l}0.5 \\
47\end{array}$ & $\begin{array}{c}0.4 \\
88\end{array}$ & $\begin{array}{c}0.50 \\
0\end{array}$ & $\begin{array}{c}0.45 \\
8\end{array}$ & $\begin{array}{c}0.45 \\
4\end{array}$ & $\begin{array}{c}0.46 \\
3\end{array}$ & $\begin{array}{c}0.48 \\
3\end{array}$ & $\begin{array}{c}0.44 \\
4\end{array}$ & $\begin{array}{c}0.46 \\
3\end{array}$ & $\begin{array}{c}0.44 \\
6\end{array}$ & $\begin{array}{c}0.44 \\
1\end{array}$ & $\begin{array}{c}0.42 \\
8\end{array}$ \\
\hline
\end{tabular}

Note: The data is original from World Economic Database (WTO database), eliminating government service.

As shown in Table 5, we can see that after the accession to WTO, the values of China's RCA from 2002 to 2013 are all less than 0.8, which shows that the international competitiveness of China's service trade is still weak during this period.

\section{Strategies to Improve the International Competitiveness of China's Service Trade}

Through the above analysis, we can find that after the accession to WTO, the total import and export volume of China's service trade per year is increasing. But on the whole, the international competitiveness of China's service trade is relatively weak. Service trade is an industry with the greatest potential growth in modern economy. Therefore, we should take measures to improve its international competitiveness.

To expand the service industry. According to the status and characteristics of the development of China's service industry, we should analyze its strengths and weaknesses. Combined with China's commitments after the accession to WTO and the situation of our country, we should determine the opening of China's service industry and its retention. For the areas with rapid development of China's service industry, such as Guangdong, Fujian, Shanghai, we could speed up its opening pace. For the central and western regions, gradual opening could be expected. For Hong Kong, Macao and Taiwan, even the full opening could be within consideration.

To strengthen the government supporting of service enterprises. Our government can take a variety of measures to support the service enterprises, so as to promote service trade. For instance, the government can implement some preferential tax policies to promote its development, and provide the service enterprises with much more accurate information of international service trade. In addition, it can provide special funds to support the emerging service industry with potential advantages, so as to promote the development of China's service trade.

To strengthen the training of service trade talents. Service trade talents are of great importance in the better development of service trade. Our country should strengthen the training of service trade talents to make them fully understand and master GATs. Meanwhile, they will become compound talents in international service trade.

\section{References}

[1] YIN Xiaobo \& YUAN Yongyou. 2013. International Service Trade, Dongbei University of Finance \& Economics Press.

[2] ZHANG Bo. 2013. Introduction to Foreign Trade of China. China Renmin University Press. 
[3] ZHUANG Huiming \& BAO Ting. A Research on the Competitiveness of China's Service Trade Based on Service Trade Openness [J], East China Economic Management, 2014, 01, 51-54. 